\title{
Cyclophosphamide increases the frequency of sister chromatid exchange in direct preparations of human chorionic villi in the absence of supplementary enzymatic activation systems
}

\author{
S Pariani, M Buscaglia, M Piantanida, G Simoni
}

\begin{abstract}
A study was performed to evaluate the effect on the frequency of sister chromatid exchange in first trimester chorionic villi of two chemical compounds, mitomycin $C$ and cyclophosphamide. Mitomycin $\mathbf{C}$ is generally known to induce an increase in sister chromatid exchange both in vivo and in vitro standard conditions. Cyclophosphamide is a compound requiring additional enzymatic enrichment of the culture medium to express its mutagenic activity under in vitro conditions. We exposed chorionic villi samples to these chemicals without the use of conventional cell cultures and without adding enzymatic extracts to the medium. The results indicate a statistically significant increase in the frequency of sister chromatid exchange after exposure to both compounds and also at lower dosages.
\end{abstract}

Sister chromatid exchanges (SCEs) are considered to be sensitive indicators of genetic effects after exposure to mutagenic agents. ${ }^{1-4}$ Cells treated with a variety of chemical and physical mutagenic and carcinogenic agents show an increased level of SCEs, both in vivo and in vitro conditions. ${ }^{5}$ However, studies of chemically induced mutagenesis in vivo and in vitro differ greatly both in experimental techniques and conclusions. ${ }^{67}$ Moreover it is necessary to make a distinction between indirect mutagens, such as cyclophosphamide (CP), and direct ones, such as mitomycin $\mathrm{C}$ (MMC).

Mitomycin C is generally recognised to induce an increased frequency of SCEs, both in vivo and in lymphocyte and skin fibroblast cultures. ${ }^{8-10}$ However, cyclophosphamide, an antitumoural drug, shows mutagenic effect in vitro only after previous metabolic activation, normally present in vivo. ${ }^{11} 12 \mathrm{CP}$ is metabolised by the liver yielding highly reactive alkylating compounds. Therefore, $\mathrm{CP}$ activation in vitro requires enrichment of culture systems with liver enzymatic extracts.

The alternative is to test the substance on a biological system that maintains sufficient enzymatic activity in vitro to permit expression of the substance itself. Recently, Carrera et $a^{13}$ tested the genetic effect of ultrasound using SCE analysis in spontaneous metaphases from chorionic villi, thus illustrating the possibility of investigating directly the effects of mutagenic agents in a human organised tissue structure without the need for cell culture.

In this paper, assuming the presumptive functional integrity of chorionic villi, we investigated their capacity to show not only the effects of direct mutagens, such as MMC, but also of chemicals requiring enzymatic activation, such as CP.

\section{Materials and methods}

Two series of experiments were performed. In the first series, three samples of first trimester chorionic villi obtained from voluntary termination of pregnancy were exposed to MMC. In the second, CP was tested on four samples of chorionic villi. In both experiments SCE frequencies were evaluated by comparing different concentrations of the agents to baseline conditions: $\mathrm{MMC}$ and CP were tested at 5 and $10 \mathrm{ng} / \mathrm{ml}$ and at 100 and $200 \mu \mathrm{g} / \mathrm{ml}$ final concentrations, respectively. CP was also compared to a positive control ( $5 \mathrm{ng} / \mathrm{ml} \mathrm{MMC}$ ).

\section{VISUALISATION AND EXPOSURE OF SCES}

Chorionic villi sampled from 8 to 10 weeks voluntary abortions were selected under an inverted microscope $(50 \times)$ and washed in Hank's balanced salt solution. Aliquots of about $20 \mathrm{mg}$ were transferred into $35 \mathrm{~mm}$ plastic Petri dishes containing $3 \mathrm{ml}$ of RPM-I 1640 medium with $5 \%$ fetal calf serum and antibiotics. ${ }^{14}$ Villi were recovered in a humidified incubator with $5 \% \mathrm{CO}_{2}$ at $37^{\circ} \mathrm{C}$ for almost three to four hours before addition of $10 \mu \mathrm{g} / \mathrm{ml}$ BrdU and treatment with testing chemicals. MMC (Sigma), reconstituted and serially diluted in $\mathrm{PBS}$ without $\mathrm{Ca}++$ and $\mathrm{Mg}++$, was added to the dishes at $5 \mathrm{ng} / \mathrm{ml}$ and $10 \mathrm{ng} /$ $\mathrm{ml}$ final concentrations. CP (Endoxan-Asta, Schering) was reconstituted in distilled water, diluted in Hank's balanced salt solution, and added to the dishes at 100 and $200 \mu \mathrm{g} / \mathrm{ml}$ final concentrations. Villi were then incubated for 72 hours and colcemid was added in a concentration of $0.08 \mu \mathrm{g} / \mathrm{ml}$ during the last three hours before harvesting.

Chromosome preparations were performed according to the procedure described by Simoni et $a l^{15}$ and visualisation of SCEs was obtained by acridine orange staining. ${ }^{16}$ The frequency of SCEs was evaluated in second division cells with no less than 44 chromosomes. The number of cells scored was either 
Table 1 SCE frequency in second division metaphases after exposure to MMC of chorionic villi specimens obtained from three first trimester voluntary abortions.

\begin{tabular}{|c|c|c|c|c|c|c|}
\hline \multirow[t]{2}{*}{ Specimen } & \multicolumn{2}{|c|}{$\begin{array}{l}\text { Control } \\
\text { SCEs/cell }\end{array}$} & \multicolumn{2}{|c|}{$\begin{array}{c}\text { MMC } 5 \mathrm{ng} / \mathrm{ml} \\
\text { SCEs/cell }\end{array}$} & \multicolumn{2}{|c|}{ 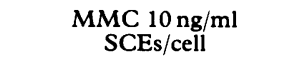 } \\
\hline & Average & Range & Average & Range & Average & Range \\
\hline $\begin{array}{l}1^{*} \\
2 \dagger \\
3^{*}\end{array}$ & $\begin{array}{l}3 \cdot 6 \\
3 \cdot 8 \\
3 \cdot 45 \\
3 \cdot 6\end{array}$ & $\begin{array}{l}(2-7) \\
(1-8) \\
(2-6)\end{array}$ & $\begin{array}{l}10 \cdot 2 \\
13 \cdot 6 \\
12 \cdot 24 \\
12\end{array}$ & $\begin{array}{r}(7-16) \\
(10-20) \\
(10-15)\end{array}$ & $\begin{array}{l}17 \cdot 7 \\
18 \\
16 \cdot 3 \\
17 \cdot 3\end{array}$ & $\begin{array}{l}(12-30) \\
(14-24) \\
(10-23)\end{array}$ \\
\hline
\end{tabular}

Mann-Whitney Test

$\mathrm{C}_{(1-3)}-\mathrm{MMC}_{(1-3)} \quad \mathrm{p} \ll 0.01$

MMC $5_{(1-3)}-M M C 10_{(1-3)} \quad$ p $\ll 0.01$

No of metaphases analysed for each treatment: $* 25,+30$

Table 2 SCE frequency in second division metaphases after exposure to CP of chorionic villi specimens obtained from four first trimester voluntary abortions.

\begin{tabular}{|c|c|c|c|c|c|c|c|c|}
\hline \multirow[t]{2}{*}{ Specimen } & \multicolumn{2}{|c|}{$\begin{array}{l}\text { Control } \\
\text { SCEs/cell }\end{array}$} & \multicolumn{2}{|c|}{$\begin{array}{l}\text { Positive control* } \\
\text { SCEs/cell }\end{array}$} & \multicolumn{2}{|c|}{$\begin{array}{l}\mathrm{CP} 100 \mu \mathrm{g} / \mathrm{ml} \\
\text { SCEs/cell }\end{array}$} & \multicolumn{2}{|c|}{$\begin{array}{l}\mathrm{CP} 200 \mu \mathrm{g} / \mathrm{ml} \\
\text { SCEs/cell }\end{array}$} \\
\hline & Average & Range & Average & Range & Average & Range & Average & Range \\
\hline $\begin{array}{l}1 \dagger \\
2 \ddagger \\
3 \ddagger \\
4 \ddagger\end{array}$ & $\begin{array}{l}3 \cdot 8 \\
3 \cdot 6 \\
3 \cdot 4 \\
3 \cdot 04 \\
3 \cdot 45\end{array}$ & $\begin{array}{l}(1-8) \\
(2-6) \\
(1-6) \\
(1-7)\end{array}$ & $\begin{array}{l}13.5 \\
12.5 \\
13.2 \\
11.5 \\
12.7\end{array}$ & $\begin{array}{r}(10-20) \\
(10-16) \\
(11-16) \\
(9-15)\end{array}$ & $\begin{array}{l}12 \\
10 \cdot 6 \\
12 \cdot 7 \\
10 \cdot 2 \\
11 \cdot 4\end{array}$ & $\begin{array}{l}(8-16) \\
(8-16) \\
(8-17) \\
(8-18)\end{array}$ & $\begin{array}{l}\overline{17 \cdot 4} \\
24 \cdot 4 \\
17 \\
19 \cdot 6\end{array}$ & $\begin{array}{c}- \\
(14-27) \\
(14-36) \\
(12-24)\end{array}$ \\
\hline
\end{tabular}

Mann-Whitney Test
$\mathrm{C}_{(1-4)}-\mathrm{CP} 100_{(1-4)} \quad \mathrm{p} \ll 0.01$.

CP $100_{(1-4)}-$ CP $200_{(2-4)} \quad \mathrm{p} \ll 0.01$.

* Positive control: mytomicin C $5 \mathrm{ng} / \mathrm{ml}$.

No of metaphases analysed for each treatment: $\ddagger 25, \uparrow 30$.

25 or 30 for each treatment and specimen (table 1).

\section{Results and discussion \\ MMC EXPOSURE}

As summarised in table 1 a baseline value of 3.6 SCEs/cell was observed in control samples, while mean values of 12 and $17 \cdot 3$ SCEs/cell were observed after treatment with 5 and $10 \mathrm{ng} / \mathrm{ml}$ MMC, respectively. Statistical analysis, according to the Mann-Whitney test for large samples, ${ }^{17}$ showed significant differences between the frequency of SCEs in exposed and control villi. In addition a significant difference was found when comparing the two concentrations of the compound.

\section{CP EXPOSURE}

The results of chorionic villi exposure to $\mathrm{CP}$ are shown in table 2 . Chorionic villi showed their sensitivity to the presence of CP in the medium and the effect on the frequency of SCEs/cell increased with the concentration of the agent. In fact, after exposure of villi specimens to 100 and $200 \mu \mathrm{g} / \mathrm{ml}$ of $\mathrm{CP}$, the frequency of SCEs/cell was 11.4 and 19.6 respectively, which was statistically significant when compared to $3.4 \mathrm{SCEs} /$ cell baseline value. Moreover, a significant increase was found comparing the SCE frequency of the two dosages we tested. Exposure to $5 \mathrm{ng} / \mathrm{ml}$ MMC was used as a positive control and yielded a significantly higher frequency of SCEs than baseline value of unexposed villi.

It should be noted that the frequency of SCEs in untreated chorionic villi cells was found to be lower than that generally reported for human lymphocytes and fibroblasts. ${ }^{81819}$ In the present study, the statistically significant increase in SCEs occurred with a lower concentration of the two chemicals than used in previous reports on cultured cells.

All this might suggest that uncultured chorionic villi are very sensitive indicators of the mutagenic effect on chromosomes of chemical agents.

\section{Conclusions}

Chorionic villi appear to maintain a structural and functional integrity in vitro, sufficient to react to indirect mutagens without the addition of enzymatic extracts to the culture medium. In our study, samples of chorionic villi exposed to a direct mutagen, MMC, and to an indirect one, CP, showed a significant increase in SCEs/cell frequency compared to controls.

These results indicate that the mutagenic effect at the chromosomal level can be investigated without conventional cell culture. In fact, spontaneous cell proliferation of chorionic villi has been shown to be adequate for this purpose and indirect chemical mutagens requiring metabolic activation seem to be satisfactorily tested by this semi-in vivo system.

The authors would like to thank Professor $M$ Fraccaro for helpful comments on the manuscript. This study was supported by grants from ASM, Associazione Italiana Studio delle Malformazioni, Milano.

1 Solomon E, Bobrow M. Sister chromatid exchanges - a sensitive assay of agents damaging human chromosomes. Mutat Res 1975;30:273-8.

2 Latt SA. Sister chromatid exchanges. Genetics 1979, 92(suppl):83-95

3 Wolff S, Carrano AV. Report of the workshop on the utility of sister chromatic exchanges. Mutat Res 1979;64:53-6.

4 Nakanishi Y, Schneider EL. In vivo sister chromatid exchanges: a sensitive measure of DNA damage. Mutat Res 1979;60:329-37. 
5 Gebhart E. Sister chromatid exchange (SCE) and structural chromosomal aberration in mutagenicity testing. Hum chromosomal aberration

6 Perry P, Evans HJ. Cytological detection of mutagencarcinogen exposure by sister chromatid exchanges. Nature 1975;258:121-5.

7 Bochkov NP, Filippova TV, Kuzin SM, Stukalov SV. Cytogenetic effects of cyclophosphamide on human lymphocytes in vivo and in vitro. Mutat Res 1986;159:103-7.

8 Latt SA. Sister chromatid exchanges, indices of human damage and repair: detection by fluorescence and induction by mitomycin C. Proc Natl Acad Sci USA 1974;71:3162-6.

9 Huttner KM, Ruddle FH. Study of mitomycin C-induced chromosomal exchange. Chromosoma 1976;56:1-13.

10 Kram D, Schneider EL, Senula GC, Nakanishi Y. Spontaneous and mitomycin C-induced sister chromatid exchanges. Comparison of in vivo and in vitro systems. Mutat Res 1979;60:339-47.

11 Stetka DG, Wolff S. Sister chromatid exchange as an assay for genetic damage induced by mutagen-carcinogens. II. for genetic damage induced by mutagen-carcinogens. I1. In vitro test for compounds requit
tion. Mutat Res $1976 ; 41: 343-50$.

12 Lindhall-Kiessling K, Karlberg I, Olofsson AM. Induction of sister chromatid exchanges by direct and indirect mutagens in human lymphocytes, co-cultured with intact rat liver cells. Effect of enzyme induction and preservation of the liver cells by freezing in liquid nitrogen. Mutat Res 1989;211:77-87.
13 Carrera P, Orsini S, Terzoli G, Brambati B, Simoni G. Sister chromatid exchanges in first trimester chorionic villi after in vivo and in vitro exposure to diagnostic villi after in vivo and in vitro exposure
ultrasound. Prenat Diagn 1990;10:141-8.

14 Terzoli G, Romitti L, Guerneri S, Carrera P, Camurri L. Effect of incubation time and serum concentration on the number of mitoses in aspirated villi samples. In: Fraccaro M, Simoni G, Brambati B, eds. First trimester fetal diagnosis. Berlin: Springer-Verlag, 1985:197-200.

15 Simoni G, Brambati B, Danesino C, et al. Efficient direct chromosome analysis and enzyme determination from chorionic villi samples in the first trimester of pregnancy. Hum Genet 1983;63:349-57.

16 Dutrillaux MB, Laurent C, Couturier J, Lejeune J. Coloration des chromosomes humains par l'acridine orange après le traitment par le 5-bromodeoxiuridine. $C R$ Acad $S c i[D]$ 1973;276:3175-81.

17 Siegel S. Non parametric statistics for the behavioral sciences. New York: McGraw-Hill, 1956:116-27.

18 Mazzullo HA, Attwood J, Delhanty JDA. Familial polyposis coli: no evidence for increased sensitivity to mitomycin C. $\mathcal{f}$ Med Genet 1988;25:233-7.

19 Yokota K, Ueda K, Ohama K, Fujiwara A. Increased spontaneous and mitomycin $\mathrm{C}$-induced SCEs in patients with cancer of the cervix uteri, with special reference to stage of cancer. Cancer Genet Cytogenet 1989;43:79-87. 